\title{
Exendin-4 inhibits interleukin-1 $\beta$-induced iNOS expression at the protein level, but not at the transcriptional and posttranscriptional levels, in RINm5F $\beta$-cells
}

\author{
Jung-Hoon Kang ${ }^{1}$, Seo-Yoon Chang ${ }^{1}$, Hyun-Jong Jang ${ }^{1}$, Dong-Bin Kim², Gyeong Ryul Ryu ${ }^{2}$, \\ Seung Hyun $\mathrm{Ko}^{2}$, In-Kyung Jeong ${ }^{3}$, Yang-Hyeok Jo ${ }^{1}$ and Myung-Jun Kim ${ }^{1}$ \\ Departments of ${ }^{1}$ Physiology and ${ }^{2}$ Internal Medicine, College of Medicine, The Catholic University of Korea, Seoul 137-701, South Korea \\ ${ }^{3}$ Department of Internal Medicine, School of Medicine, Kyung Hee University, Seoul 130-701, South Korea \\ (Correspondence should be addressed to M-J Kim; Email: mjunkim@catholic.ac.kr)
}

\begin{abstract}
Cytokines such as interleukin-1 $\beta$ (IL-1 $\beta$ ) stimulate inducible nitric oxide synthase (iNOS) expression and nitric oxide overproduction leading to $\beta$-cell damage. Meanwhile, glucagon-like peptide-1 (GLP-1) and its potent analog exendin-4 (EX-4) were well known for $\beta$-cell proliferation. However, the protective mechanisms of GLP-1 in $\beta$-cells exposed to cytokines were not fully elucidated. Therefore, the effects of EX-4 on the IL-1 $\beta$-induced iNOS gene expression were investigated employing RINm5F $\beta$-cells. EX-4 inhibited IL-1 $\beta$-induced iNOS protein expression and nitrite production. However, northern blot and promoter analyses showed that EX-4 failed to inhibit IL-1 $\beta$-induced iNOS mRNA expression and iNOS promoter activity. By electrophoretic mobility shift assay (EMSA), EX-4 did not alter the binding activity of NF- $\kappa \mathrm{B}$ to the iNOS promoter. Consistent with the EMSA result, EX-4 did not inhibit nuclear translocation of p65. We also tested the effect of EX-4 on
\end{abstract}

iNOS mRNA stability. Actinomycin D chase experiments showed that EX-4 did not affect the decay rate of iNOS mRNA and the promoter assay using the construct containing $3^{\prime}$-untranslated region of iNOS showed that EX-4 did not alter the stability of iNOS mRNA. Meanwhile, forskolin significantly inhibited IL-1 $\beta$-induced iNOS protein, which was reversed by $\mathrm{H}-89$, a protein kinase A (PKA) inhibitor. Moreover, EX-4 pretreatment restored IL- $1 \beta$-induced decrease in cAMP toward control level. Additionally, the cycloheximide chase study demonstrated that EX-4 significantly accelerated iNOS protein degradation. We therefore concluded that EX-4 inhibited IL- $1 \beta$-induced iNOS protein and nitrite production via cAMP/PKA system irrespective of both transcriptional and posttranscriptional mechanisms of iNOS gene, and this inhibitory effect of EX-4 appears to be regulated at posttranslational level.

Journal of Endocrinology (2009) 202, 65-75

\section{Introduction}

The main feature of type 1 diabetes mellitus is an autoimmune insulitis, that is, the infiltration of inflammatory cells around the pancreatic islets (Andre et al. 1996). The insulitis is primarily mediated by proinflammatory cytokines such as interleukin-1 $\beta$ (IL-1 $\beta$ ), tumor necrosis factor- $\alpha$ (TNF- $\alpha$ ) and interferon- $\boldsymbol{\gamma}$ (INF- $\boldsymbol{\gamma}$; Mandrup-Poulsen 2001). Specifically, IL-1 $\beta$ induces the expression of inducible nitric oxide synthase (iNOS) in islet $\beta$-cells leading to the overproduction of nitric oxide (NO) that mediates cytotoxicity of $\beta$-cells (Southern et al. 1990, Rabinovitch 1998).

Accumulating evidence shows that $\beta$-cells are the primary source of cytokine-induced free radical formation (Salehi et al. 1996, Tabatabaie et al. 2003). In particular, low antioxidant defense systems of $\beta$-cells are considered to be a target of free radicals, leading to $\beta$-cell dysfunction and type 1 diabetes mellitus (Ho \& Bray 1999). Some previous studies indicate that NO scavengers or reduction of iNOS enzyme activity have been implicated in the protection of $\beta$-cells exposed to cytokines (Corbett \& McDaniel 1992, Mandrup-Poulsen 1996). In addition, though inflammatory cytokines IL-1 $\beta$, TNF- $\alpha$, and INF- $\gamma$ signal via different receptors, these combined cytokines induce numerous target genes including iNOS. Among these genes, almost $50 \%$ are NO-dependent, which suggests a pivotal role of iNOS in cytokine-mediated $\beta$-cell injury (Kutlu et al. 2003). Therefore, the approaches to inhibit or reduce iNOS expression may be necessary for the prevention or inhibition of $\beta$-cell damage.

Glucagon-like peptide-1 (GLP-1) and its potent agonist exendin-4 (EX-4) have received great attention because of their insulinotropic and $\beta$-cell-proliferating effects (Ørskov 1992, Egan et al. 2003, Bulotta et al. 2004, Baggio \& Drucker 2007). Both GLP-1 and EX-4 activate multiple signaling pathways such as cAMP/protein kinase A (PKA) system, 
phosphatidylinositol 3-kinase, and mitogen-activated protein kinase (MAPK), which lead to $\beta$-cell maintenance and growth (Jhala et al. 2003, List \& Habener 2004, Stoffers 2004). In addition, GLP-1 induces immediate early response genes such as c-fos, c-jun, and early growth response-1 (Egr-1), which are involved in $\beta$-cell growth and differentiation (Susini et al. 1998, Stoffers 2004). Recently, we found that EX-4 induces transcriptional activation of cyclin D1 and Egr-1 genes, which were known to be involved in cell proliferation, in INS-1 $\beta$-cells (Kang et al. 2006, 2007, Kim et al. 2006, 2008).

Despite diverse effects of GLP-1, its protective mechanisms on cytokine-induced iNOS expression are incompletely understood. GLP-1 and glucagon reduced NO production through the cAMP level increase, in high glucose- and IL-1 $\beta$-stimulated islets respectively (Belin et al. 1999, Jimenez-Feltstrom et al. 2005). GLP-1 suppressed excessive $\mathrm{NO}$ generation and iNOS activity in diabetic rat islet via the activation of cAMP/PKA system (Salehi et al. 2008). EX-4 decreased cytokine-induced iNOS protein expression through protein kinase B activation in INS-1 cells (Li et al. 2005). However, these studies were mainly limited at the levels of iNOS protein expression and enzyme activity. Therefore, this study was aimed to explore the inhibitory effects of EX-4 on IL-1 $\beta$-induced iNOS expression focusing on iNOS gene transcription mechanism.

\section{Materials and Methods}

\section{Materials}

RINm5F (CRL-11605) cells, a rat insulinoma cell line, were obtained from American Type Tissue Collection (Manassas, VA, USA). FBS, RPMI 1640 medium, and OPTI-MEM were purchased from Gibco BRL. EX-4 was from Bachem AG (Torrance, CA, USA). Recombinant human IL-1 $\beta$ and Cyclic AMP Assay kit were from R\&D systems (Minneapolis, MN, USA). Forskolin, PD98059, SB203580, H-89, and cycloheximide were from Calbiochem (La Jolla, CA, USA). AccuPrep genomic DNA extraction kit was from Bioneer (Daejon, Korea). Top-Pfu DNA polymerase was from BioOnline (Seoul, Korea). Lipofectamine 2000 reagent was from Invitrogen. BCA protein assay kit was from Perbio Science (Erembodegem, Belgium). Griess Reagent System, pGL3 Luciferase Reporter Vector, pSV- $\beta$-gal, pGEM-T Easy Vector, and T4 polynucleotide kinase were from Promega. Anti-mouse iNOS antibody was from BD Transduction Laboratories (Palo Alto, CA, USA). Western blotting Luminol reagent, NF- $\mathrm{B}$ oligonucleotides probe, and antip65 antibody were from Santa Cruz Biotechnology (Santa Cruz, CA, USA). RNA STAT-60 was from TEL-TEST (Friendswood, TX, USA). First Strand cDNA Synthesis Kit, alkaline phosphatase-conjugated anti-dogoxigenin (DIG) antibody, and CDP-Star was from Roche Diagnostics. All other reagents were purchased from Sigma. EX-4 was prepared in RPMI 1640 containing $0 \cdot 1 \%$ BSA to prevent the peptide from adherence to plastic surfaces. Forskolin was dissolved in ethanol at $100 \mathrm{mM}$ stock solution. PD98059, SB203580, and H-89 were dissolved in DMSO at $100 \mathrm{mM}$ stock solution and added to the culture medium. The final concentration of vehicles did not exceed $0 \cdot 1 \%$.

\section{Drugs treatment}

RINm5F cells were cultured in RPMI-1640 medium supplemented with $10 \%$ FBS, $2 \mathrm{mM}$ L-glutamine, and antibiotics $(100 \mathrm{U} / \mathrm{ml}$ penicillin and $100 \mathrm{U} / \mathrm{ml}$ streptomycin), and maintained at $37^{\circ} \mathrm{C}$ in humidified air containing $5 \% \mathrm{CO}_{2}$. Cells were subcultured weekly and passages 19-30 were used exclusively. We fixed the concentration $(100 \mathrm{pg} / \mathrm{ml})$ and incubation time of IL-1 $\beta$ based on our previous study (Kim et al. 2004). The cells were plated at a concentration of $2 \times 10^{5} / \mathrm{ml}$ except for transient transfection experiment. At $70 \%$ confluency, the cells were incubated with serum-free RPMI medium for $16 \mathrm{~h}$, and then pretreated with EX-4 (1 or $10 \mathrm{nM})$ and forskolin $(10 \mu \mathrm{M})$ for 30 or $60 \mathrm{~min}$, and next incubated with IL-1 $\beta(100 \mathrm{pg} / \mathrm{ml})$ for indicated times. Pharmacological inhibitors (H-89 (5 $\mu \mathrm{M})$ : a PKA inhibitor; PD98059 $(10 \mu \mathrm{M})$ : an MEK inhibitor; SB203580 (10 $\mu \mathrm{M})$ : p38 MAPK inhibitor) were added $30 \mathrm{~min}$ prior to stimulation of cells with IL-1 $\beta$ and EX-4.

\section{Measurement of $\mathrm{NO}$ as nitrite}

RINm5F cells were treated with EX (1 and $10 \mathrm{nM})$ for $1 \mathrm{~h}$, and then incubated with IL-1 $\beta(100 \mathrm{pg} / \mathrm{ml})$ for an additional $24 \mathrm{~h}$. Released nitrite, a stable product of $\mathrm{NO}$ in aqueous medium, was measured using Griess Reagent System as described previously (Kim et al. 2004). Briefly, the culture medium was mixed with an equal volume of sulfanilamide solution ( $1 \%$ in $5 \%$ phosphoric acid) and of N-1-naphtylethylenediamine dihydrochloride solution $(0 \cdot 1 \%$ in water $)$. The absorbance was measured at $540 \mathrm{~nm}$ on MR700 Microplate Reader (Dynatech Laboratories Inc., Chantilly, VA, USA). Nitrite concentrations were then determined from a calibration curve of standard $\mathrm{NaNO}_{2}$ concentrations against absorbance. Data are expressed as $\mathrm{mM}$ per $\mathrm{mg}$ protein to adjust for the differences in the cell mass among the groups.

\section{Western blot analysis}

RINm5F cells were treated with EX-4 (1 and $10 \mathrm{nM})$ or $N$-nitro-L-arginine methylester (L-NAME, $1 \mathrm{mM}$ ) for $1 \mathrm{~h}$, and then incubated with IL-1 $\beta(100 \mathrm{pg} / \mathrm{ml})$ for an additional $16 \mathrm{~h}$. Western blot analysis was performed essentially as described previously (Kim et al. 2004, 2006). Briefly, the cells were harvested, and solubilized with RIPA buffer $(25 \mathrm{mM}$ Tris-HCl, $\mathrm{pH} 7 \cdot 4,0 \cdot 1 \%$ SDS, $0 \cdot 1 \%$ Triton X-100, $1 \%$ sodium deoxycholate, $150 \mathrm{mM} \mathrm{NaCl}, 1 \mathrm{mM}$ EDTA, $1 \mathrm{mM}$ 
$\mathrm{Na}_{3} \mathrm{VO}_{4}, 1 \mathrm{mM}$ phenylmethylsulphonyl fluoride, $10 \mu \mathrm{g} / \mathrm{ml}$ aprotinin, and $5 \mu \mathrm{g} / \mathrm{ml}$ leupeptin). The soluble fraction was collected and protein content was determined by BCA. Thirty micrograms total protein was separated on an $8 \%$ SDS-PAGE and transferred onto nitrocellulose membrane. After blocking with 5\% skimmed milk, the membrane was incubated with anti-mouse iNOS IgG $(0.5 \mu \mathrm{g} / \mathrm{ml}$ of TTBS). Then, the membrane was probed with peroxidaseconjugated anti-mouse $\operatorname{IgG}(0 \cdot 5 \mu \mathrm{g} / \mathrm{ml}$ TTBS $)$. The signal was visualized by enhanced chemiluminescence system. For the nuclear translocation of $\mathrm{p} 65$ protein, an NF- $\mathrm{KB}$ subunit, the cells were pretreated with EX-4 for $30 \mathrm{~min}$, then incubated with IL-1 $\beta$ for $30 \mathrm{~min}$. Nuclear and cytosolic fractions were obtained using sequential hypotonic and hypertonic solutions. Equal loading and transfer of samples were verified by Ponseau S staining or the band intensity of $\beta$-tubulin (52 kDa).

\section{Northern blot analysis}

RINm5F cells were treated with EX-4 (1 and $10 \mathrm{nM})$ or NMMA $(100 \mu \mathrm{M})$ for $1 \mathrm{~h}$, and then incubated with IL-1 $\beta$ $(100 \mathrm{pg} / \mathrm{ml})$ for an additional $6 \mathrm{~h}$. Total RNA isolation and the method for northern blot analysis were described previously (Kang et al. 2006, Kim et al. 2008). The iNOS probe was demonstrated in the previous study (Kim et al. 2004). Equal loading of sample was verified by GAPDH or the ribosomal $18 \mathrm{~S}$ bands.

\section{Measurement of cellular cAMP concentration}

RINm5F cells were cultured in 6-well culture plates at a concentration of $1 \times 10^{6}$ cells/well. The cells were incubated with EX-4 $(10 \mathrm{nM})$ for $30 \mathrm{~min}$, and then incubated with IL-1 $\beta(100 \mathrm{pg} / \mathrm{ml})$ for $30 \mathrm{~min}$. The phosphodiesterase inhibitor 3-iosbutyl-1-methylxanthine (IBMX, $250 \mu \mathrm{M}$ ) were added to prevent cAMP breakdown. The cellular cAMP content was measured using cAMP assay kit according to the manufacturer's instructions. The absorbance was measured at $450 \mathrm{~nm}$ on MR700 Microplate Reader (Dynatech Laboratories Inc.).

\section{Plasmids}

Rat iNOS promoter ranging from -1173 to +33 was generated by PCR amplification method and cloned into pGL3 basic vector, then designated as piNOS-LUC (Kim et al. 2004). To examine the effect of the $3^{\prime}$-untranslated region (UTR) on iNOS mRNA stability, cDNA for $3^{\prime}$-UTR of iNOS mRNA was amplified with the primers (GenBank/EMBL accession number: U03699, forward primer: 5'-GCTCTAGACACCCAGAAGAGTTACAGCATC with XbaI (underlined), reverse primer: 5'_GCTCTAGACTTGATCAAACACTCATTTTATTAAAATA $\overline{A A A T G}$ with XbaI (underlined)). This resultant cDNA was inserted into piNOS-LUC to generate piNOS-UTR.
The construct was verified by sequencing using An ABI PRISM 310 genetic analyzer (PerkinElmer Ltd Co., Seoul, Korea).

\section{Transient transfection and luciferase reporter assay}

Transient transfection was performed by lipofection using Lipofectamine 2000 reagent as described previously (Kim et al. 2006). Briefly, RINm5F cells were plated at a density of $4 \times 10^{5} /$ well in a 6 -well plate 4 days before the transfection. Cells at $70 \%$ confluence were cotransfected

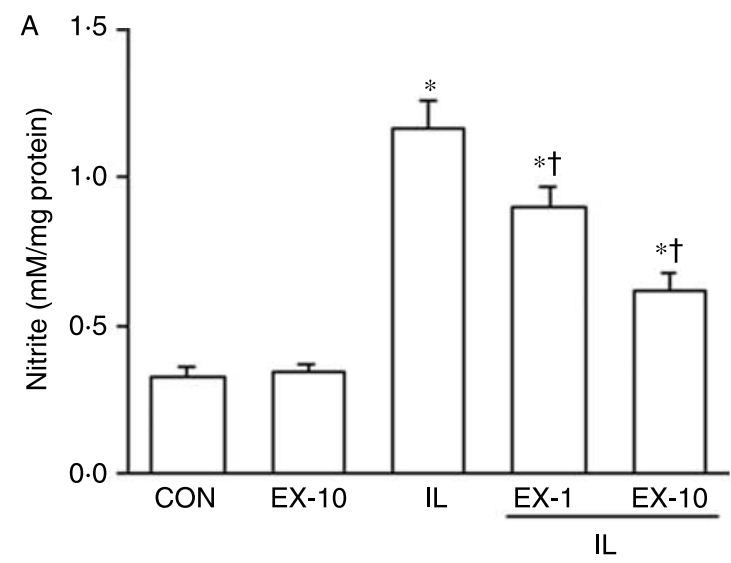

B iNOS

\section{$\beta$-tubulin}

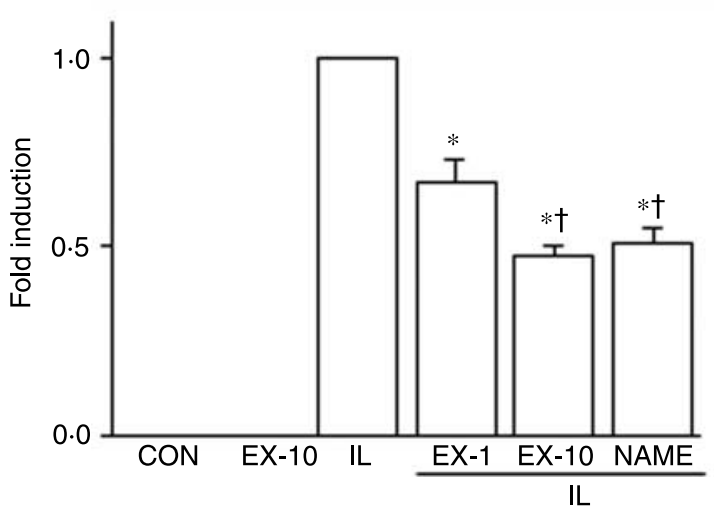

Figure 1 The inhibitory effects of exendin- 4 on IL- $1 \beta$-induced nitrite formation and iNOS protein expression in RINm5F cells. (A) The cells were pretreated with indicated doses of exendin-4 (EX, 1 and $10 \mathrm{nM})$ for $1 \mathrm{~h}$, and then incubated with IL (100 pg/ml) for an additional $24 \mathrm{~h}$. Nitrite production was measured in the same way mentioned above. Data are expressed as mean \pm s.D. $(n=4)$. ${ }^{*} P<0.05$ versus CON; ${ }^{+} P<0.05$ versus IL. (B) Following the pretreatment of EX ( 1 and $10 \mathrm{nM})$ or L-NAME $(1 \mathrm{mM})$ for $1 \mathrm{~h}$, the cells were incubated with IL $(100 \mathrm{pg} / \mathrm{ml})$ for an additional $16 \mathrm{~h}$. Western blot analysis for iNOS was performed. Equal loading of protein was verified by probing the same blot for $\beta$-tubulin. Data are expressed as mean ( \pm s.D.) of relative band density $(n=3) .{ }^{*} P<0.05$ versus IL; ${ }^{+} P<0.05$ versus $\mathrm{EX}+\mathrm{IL}$. 
with piNOS-LUC or piNOS-UTR $(1 \mu \mathrm{g})$, and pSV- $\beta$-gal $(0 \cdot 1 \mu \mathrm{g})$. Following the serum starvation for $24 \mathrm{~h}$, the cells were treated with EX-4 $(10 \mathrm{nM})$ or forskolin $(10 \mu \mathrm{M})$ for $30 \mathrm{~min}$, and then incubated with IL-1 $\beta(100 \mathrm{pg} / \mathrm{ml})$ for an additional $10 \mathrm{~h}$. Luciferase and $\beta$-galactosidase activities were measured with a luminometer (TD20/20, Turner

A
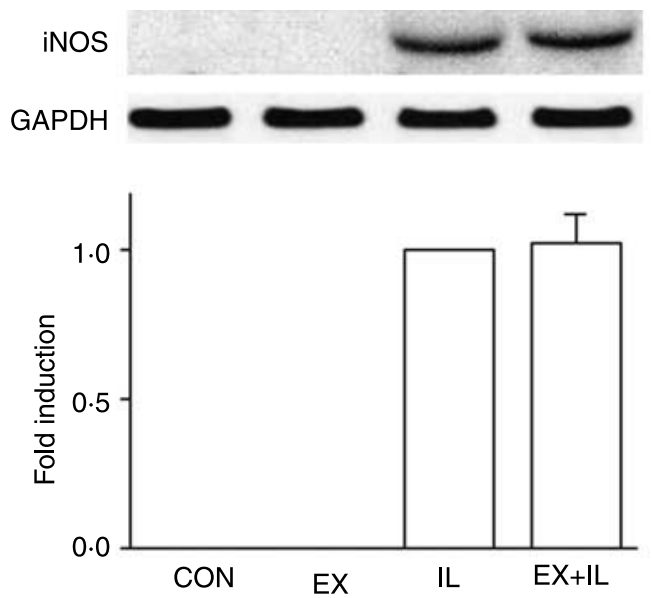

B
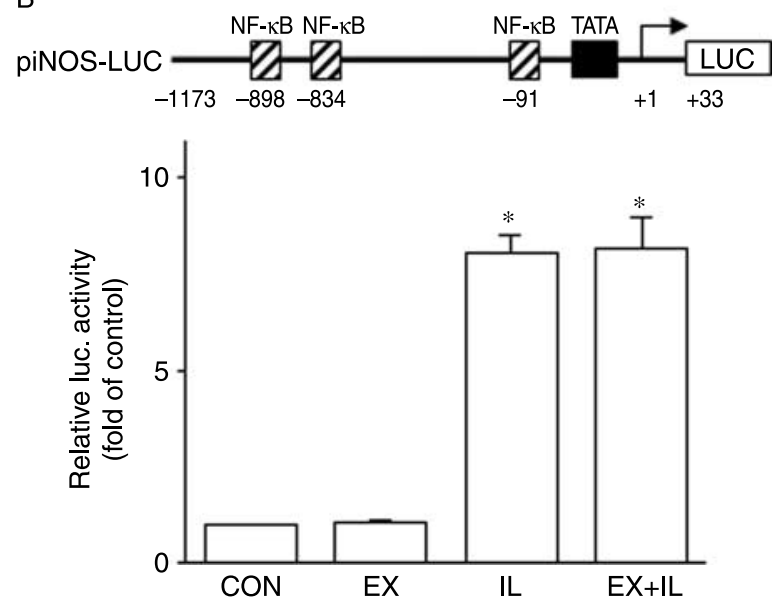

Figure 2 The effects of exendin- 4 on IL-1 $\beta$-induced iNOS mRNA expression and iNOS promoter activity in RINm5F cells. (A) The cells were pretreated with exendin- 4 (EX, $10 \mathrm{nM})$ for $1 \mathrm{~h}$, and then incubated with IL-1 $\beta$ (IL, $100 \mathrm{pg} / \mathrm{ml}$ ) for an additional $6 \mathrm{~h}$. The expressions of iNOS mRNA were measured by northern blot analysis described in materials and methods. Equal loading of sample $(10 \mu \mathrm{g})$ was verified by the GAPDH. Data are expressed as mean ( \pm s.D.) of relative band density $(n=3)$. (B) Schematic representation of the rat iNOS promoter gene focusing on NF- $\kappa$ B binding site. The cells were transiently cotransfected with piNOSLUC $(1 \mu \mathrm{g})$ and pSV- $\beta$-gal $(0 \cdot 1 \mu \mathrm{g}$, as an internal control). Following the serum starvation, the cells were pretreated with EX $(10 \mathrm{nM})$ for $30 \mathrm{~min}$, then cultured for an additional $10 \mathrm{~h}$ with $\mathrm{IL}(100 \mathrm{pg} / \mathrm{ml})$. Cells were then solubilized in lysis buffer and luciferase and $\beta$-galactosidase activities were measured. Data are expressed as mean \pm s.D. $(n=4)$ and each value is expressed relative to the control value. ${ }^{*} P<0.05$ versus CON. CON, control without any treatment; LUC, luciferase.
Designs Instrument, Sunnyvale, CA, USA) and MR700 Microplate Reader (Dynatech Laboratories Inc.) respectively. Transfection efficiencies were normalized by a ratio of luciferase activity to $\beta$-galactosidase activity obtained from the same sample.

\section{Electrophoretic mobility shift assay}

RINm5F cells were treated with EX-4 for $30 \mathrm{~min}$, and then incubated with IL-1 $\beta(100 \mathrm{pg} / \mathrm{ml})$ for $30 \mathrm{~min}$. Electrophoretic mobility shift assay (EMSA) was performed to examine the binding activity of nuclear proteins to NF- $\kappa \mathrm{B}$ binding sites of rat iNOS promoter by the method reported previously (Kim et al. 2004, 2006). For the DNA binding activity of NF- $\kappa \mathrm{B}$, the oligonucleotide probe $\left(5^{\prime}\right.$-AGTTGAGGGGACTTTCCCAGGC- $3^{\prime}$ ) containing $\kappa \mathrm{B}$ binding sites (underlined) was used. The antibody against p65, an NF- $\kappa \mathrm{B}$ subunit, was used for immune-supershift assay.

\section{iNOS mRNA stability assay}

RINm5F cells were treated with EX-4 (10 nM) for $1 \mathrm{~h}$, and then incubated with IL-1 $\beta(100 \mathrm{pg} / \mathrm{ml})$ for $6 \mathrm{~h}$, and next exposed to actinomycin D $(0.5 \mu \mathrm{g} / \mathrm{ml})$ to block RNA synthesis. The cells were harvested at $0,1,2,4$, and $6 \mathrm{~h}$ after the addition of actinomycin D. Total RNA was extracted and northern blot analysis for iNOS mRNA was performed.

\section{iNOS protein stability study}

RINm5F cells were incubated with IL-1 $\beta(100 \mathrm{pg} / \mathrm{ml})$ for $16 \mathrm{~h}$, and then exposed to cycloheximide $(2 \mu \mathrm{g} / \mathrm{ml})$ for $1 \mathrm{~h}$ to stop protein synthesis, and next treated with EX-4 (10 nM). The cells were harvested at $0,1,3$, and $6 \mathrm{~h}$ after the addition of EX-4. Total protein was extracted and western blot analysis for iNOS protein was performed.

\section{Statistical analysis}

The relative band densities were quantified using Scion Imaging software (Scion Corporation, Frederick, MD, USA). All data obtained from each experiment were expressed as mean \pm s.D. The data were analyzed using one-way ANOVA with Origin 7.0 software (Microcal Software, Northampton, MA, USA). Statistical comparisons among the groups were done by Bonferroni's multiple range $t$-test after the ANOVA. $P<0.05$ was accepted as statistically significant.

\section{Results}

Effects of EX-4 on IL-1 $\beta$-induced NO production and iNOS protein

We previously evaluated the optimal conditions to observe the effect of IL- $1 \beta$ on nitrite production in RINm5F cells. IL-1 $\beta$ significantly induced nitrite production at a 
concentration $100 \mathrm{pg} / \mathrm{ml}$ or above (Kim et al. 2004). The effect of EX-4 on IL-1 $\beta$-induced NO production were examined. EX-4 significantly inhibited IL- $1 \beta$-induced NO production (Fig. 1A). In inhibiting iNOS protein expression, EX-4 showed as much propensity as NMMA, an NOS inhibitor in RINm5F cells (Fig. 1B).

\section{Effects of EX-4 on IL-1 $\beta$-induced iNOS $m R N A$ and promoter activity}

To determine whether the effect of EX-4 on IL- $1 \beta$-induced iNOS protein expression could have resulted from the inhibition of iNOS gene transcription, we examined the iNOS mRNA expression by northern blot analysis. Contrary to our expectation, EX-4 failed to inhibit IL- $1 \beta$-induced iNOS mRNA expression (Fig. 2A). Next, we analyzed the effect of EX-4 on transactivation activities of the iNOS promoter by transient transfection experiment. Parallel to the result of iNOS mRNA expression, EX-4 did not inhibit IL-1 $\beta$-induced iNOS promoter activity (Fig. 2B).

\section{Effects of EX-4 on IL-1 $\beta$-induced NF- $\kappa B$ activation}

Since the activation of transcription factor NF- $\kappa \mathrm{B}$ is an essential step for the IL- $1 \beta$-induced iNOS expression, we evaluated the effect of EX-4 on binding activity of NF- $\kappa \mathrm{B}$ to the iNOS promoter region (Fig. 3A). Although multiple nuclear proteins $(\mathrm{C} 1-\mathrm{C} 4)$ formed complexes with the probe, the band intensity of $\mathrm{C} 2$ was strongly increased by IL-1 $\beta$. By immune-supershift EMSA using anti-p65 antibody, the supershifted band was detected (arrow in Fig. 3A), which suggests that p65 NF- $\mathrm{KB}$ subunit binds specifically to the NF- $\kappa \mathrm{B}$ binding site of the promoter. However, EX-4 did not reduce the band intensity induced by IL-1 $\beta$. The majority of DNA-protein complexes were sequence-specific because a 100-fold molar excess of unlabeled wild probe completely abolished the binding activity (Fig. 3A, 1st lane). Next, we analyzed the effect of EX-4 on the nuclear translocation of p65 by IL-1 $\beta$ (Fig. 3B). Compared with the control group, IL-1 $\beta$ induced nuclear translocation of p65. However, EX-4 did not inhibit nuclear translocation of p65 by IL- $1 \beta$.

\section{Effect of EX-4 on iNOS $m R N A$ stability}

To test the role of EX-4 in the posttranscriptional regulation of iNOS involving mRNA stability, we analyzed the degradation rate of iNOS mRNA by actinomycin D chase study. EX-4 did not alter the decay rate of iNOS mRNA induced by IL-1 $\beta$ (Fig. 4A). To further examine the effect of EX-4 on iNOS mRNA stability, we analyzed the luciferase activity using piNOS-UTR construct containing 3'-UTR of iNOS mRNA. Under basal conditions (without any treatment), the presence of $3^{\prime}-\mathrm{UTR}$ reduced luciferase activity by about $0 \cdot 5$-fold compared with the absence of $3^{\prime}$-UTR (Fig. 4B1). As shown in Fig. 4B2, IL-1 $\beta$ significantly increased the luciferase activity of piNOS-UTR, however, EX-4 did not alter the luciferase activity induced by IL-1 $\beta$.

A

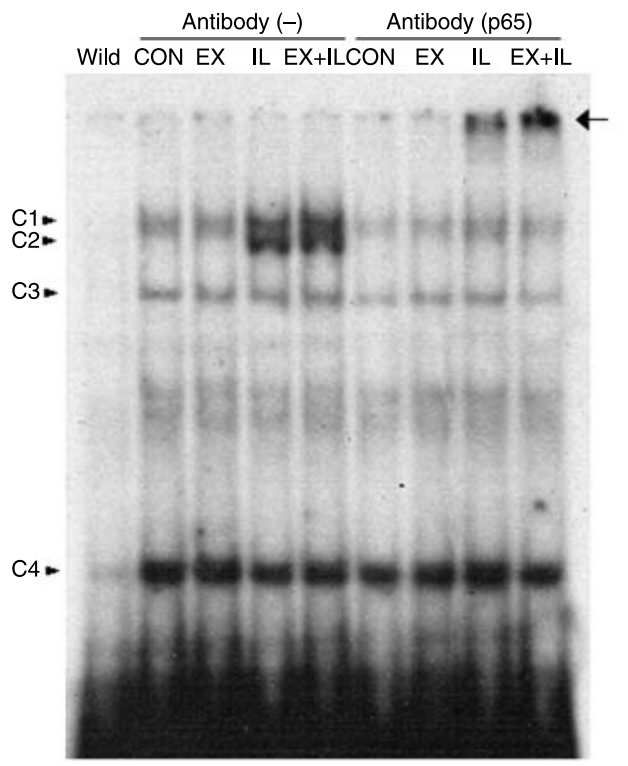

B

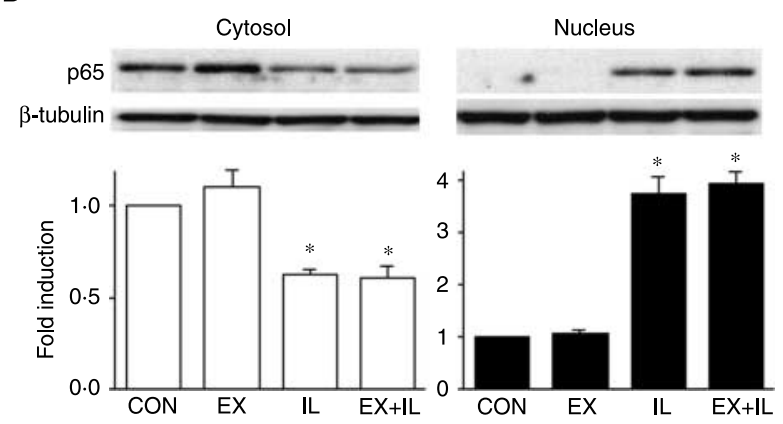

Figure 3 The effect of exendin- 4 on IL- $1 \beta$-induced NF- $\kappa B$ activation in RINm5F cells. (A) Gel mobility shift assay of NF- $\kappa B$ binding site on rat iNOS promoter. The cells were pretreated with exendin-4 (EX, $10 \mathrm{nM}$ ) for $30 \mathrm{~min}$, then incubated for 30 min with IL-1 $\beta$ (IL, $100 \mathrm{pg} / \mathrm{ml})$. Nuclear extracts were analyzed on mobility shift assay

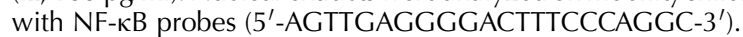
$\mathrm{C} 1-\mathrm{C} 4$ indicates the position of major DNA-protein complexes. For supershift assay, an antibody $(0 \cdot 2 \mu \mathrm{g})$ against NF- $\kappa$ B subunit (p65) was incubated with nuclear extracts for $30 \mathrm{~min}$ before the addition of probes. The arrow indicates bands supershifted by anti-p65 NF- $\kappa$ B subunit. Wild, 100-fold molar excess of unlabeled NF- $\kappa$ B probe; $\mathrm{CON}$, control without any treatment. The gel is the representative of three separate experiments with similar results. (B) The cytosolic and nuclear proteins $(30 \mu \mathrm{g})$ were separated on a $8 \%$ SDS-PAGE and the protein levels of NF-KB subunit (p65) were measured by western blot analysis. Equal loading of protein was verified by probing the same blot for $\beta$-tubulin. Data are expressed as mean \pm s.D. $(n=3)$ and each value is expressed relative to the control value. ${ }^{*} P<0 \cdot 05$ versus CON. 
The role of $A A M P$ in EX-4 inhibition of IL-1 $\beta$-induced iNOS protein

The involvement of cAMP in iNOS protein expression was evaluated since GLP-1 agonists were reported to activate cAMP/PKA pathway via GLP-1 receptor (Drucker et al.

A
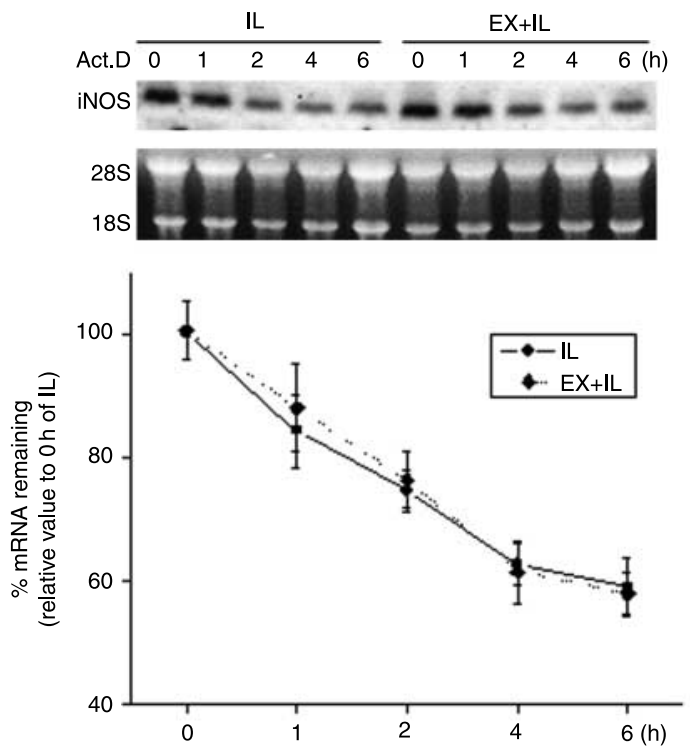

B1
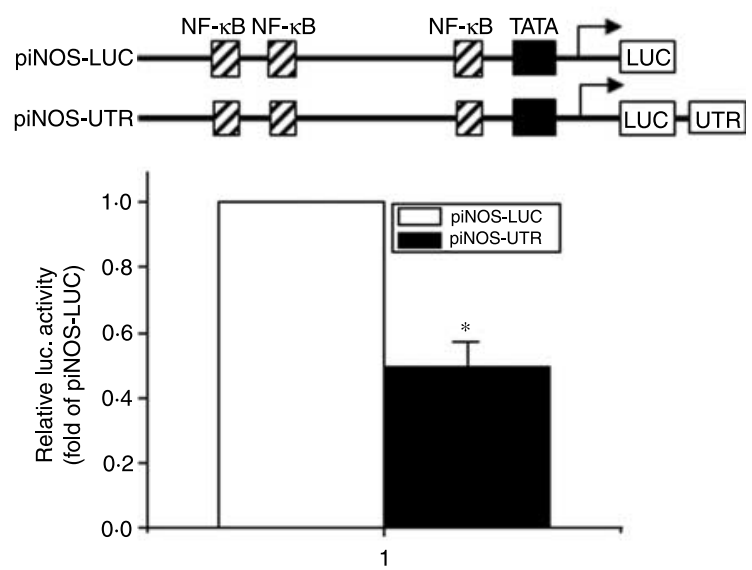

B2

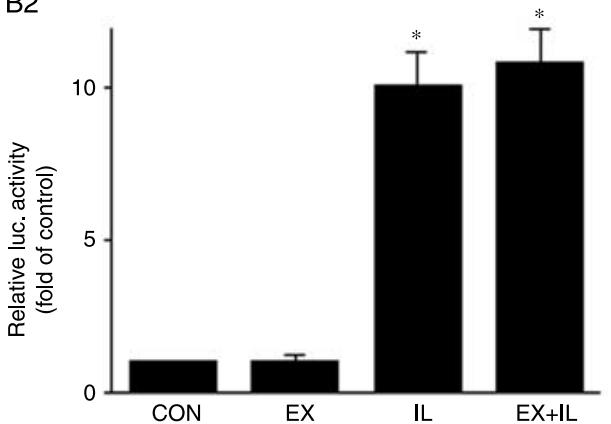

1987, Leech et al. 1999). Forskolin, a cAMP-increasing agent, significantly inhibited IL- $1 \beta$-induced iNOS protein expression, and the inhibition of iNOS protein by EX or forskolin was reversed by PKA specific inhibitor H-89 (Fig. 5A). Next, we examined the effect of forskolin on the rat iNOS promoter activity. Likewise, EX-4 and forskolin failed to inhibit IL-1 $\beta$-induced iNOS promoter activity (Fig. 5B). Based on the previous results that EX-4 induces ERK phosphorylation (Kim et al. 2006), the effect of MAPKs inhibitors on iNOS protein was observed. As shown in Fig. 5C, both PD98059, an MEK inhibitor and SB203580, a p38 MAPK inhibitor did not affect IL-1 $\beta$ induced iNOS protein expression. To evaluate further, the role of cAMP/PKA pathway, the intracellular cAMP content and iNOS protein stability were determined. EX-4 increased cAMP production dose-dependently $(0 \cdot 1-10 \mathrm{nM})$, however, a higher concentration of EX-4 (100 nM) did not increase cAMP production (Fig. 5D1). Additionally, EX-4 treatment restored the IL-1 $\beta$-induced decrease in cAMP level toward normal control level (Fig. 5D2). Next, to evaluate the effect of cAMP on iNOS protein stability, we performed pulsechase experiment using cycloheximide (Fig. 5E). EX-4 significantly increased iNOS protein degradation compared with cycloheximide alone (control). Under the influence of EX-4, the half-life of iNOS protein level induced by IL-1 $\beta$ was about $1 \mathrm{~h}$. However, in the absence of EX-4, the calculation of iNOS protein half-life was impossible because iNOS protein was only decreased by $10 \%$ even after $6 \mathrm{~h}$. This finding suggests that EX-4-induced increase in cAMP level is involved in iNOS protein degradation.

Figure 4 Effect of exendin-4 on the stability of iNOS mRNA in RINm5F cells. (A) The cells were pretreated with exendin- 4 $(\mathrm{EX}, 10 \mathrm{nM})$ for $1 \mathrm{~h}$, then with IL-1 $\beta$ (IL, $100 \mathrm{pg} / \mathrm{ml})$. After $6 \mathrm{~h}$ of incubation, actinomycin $\mathrm{D}(0.5 \mu \mathrm{g} / \mathrm{ml})$ was added to the cells. The expressions of iNOS mRNA were measured by Northern blot analysis. Equal loading of sample $(10 \mu \mathrm{g})$ was verified by the ribosomal 185 and $28 \mathrm{~S}$ bands. Data were plotted on percentage of remaining mRNA relative to $0 \mathrm{~h}$ and represent the mean \pm s.D. $(n=3)$. Act. D, actinomycin D. (B1) Schematic representation of piNOS-UTR. The cells were transiently cotransfected with piNOSLUC $(1 \mu \mathrm{g})$ and pSV- $\beta$-gal $(0 \cdot 1 \mu \mathrm{g}$, as an internal control). Following the serum starvation, the cells were then solubilized in lysis buffer, and luciferase and $\beta$-galactosidase activities were measured. Data are expressed as mean \pm s.D. $(n=4)$ and the value is expressed relative to the piNOS-LUC value. ${ }^{*} P<0 \cdot 05$ versus piNOS-LUC. LUC, luciferase; UTR, $3^{\prime}$-untranslated region of rat iNOS mRNA. (B2) The effect of exendin-4 on the luciferase activity of piNOSUTR. The cells were transiently cotransfected with piNOS-LUC $(1 \mu \mathrm{g})$ and pSV- $\beta$-gal $(0 \cdot 1 \mu \mathrm{g}$, as an internal control). Following the serum starvation, the cells were pretreated with EX $(10 \mathrm{nM})$ for $30 \mathrm{~min}$, then cultured for an additional $10 \mathrm{~h}$ with IL $(100 \mathrm{pg} / \mathrm{ml})$. The cells were then solubilized in lysis buffer, and luciferase and $\beta$-galactosidase activities were measured. Data are expressed as mean \pm s.D. $(n=4)$ and each value is expressed relative to the control value. ${ }^{*} P<0.05$ versus CON. CON, control without any treatment. 

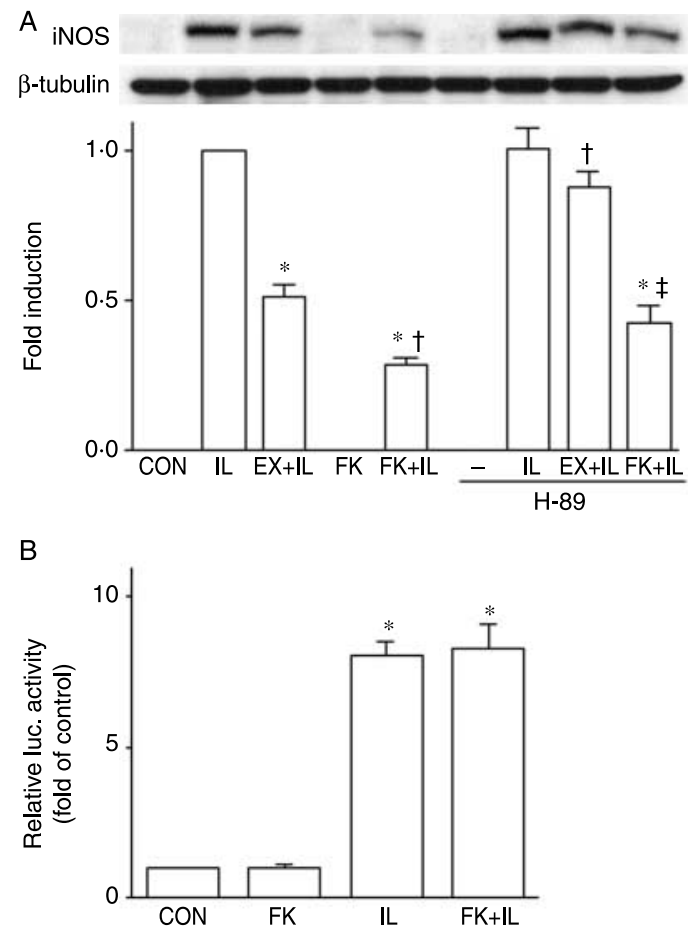

C

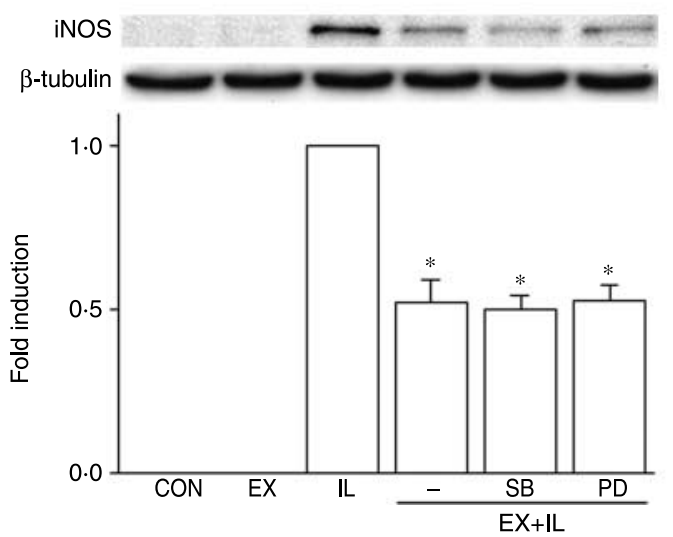

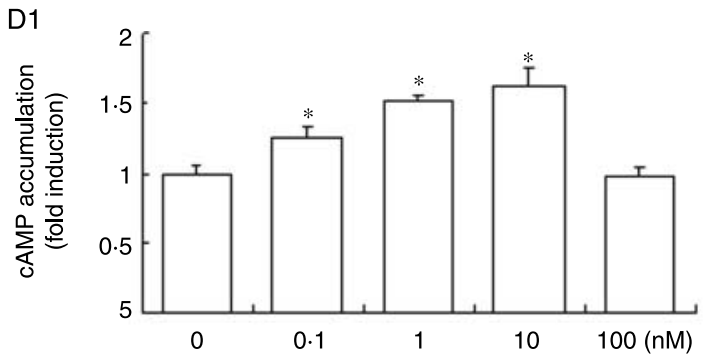

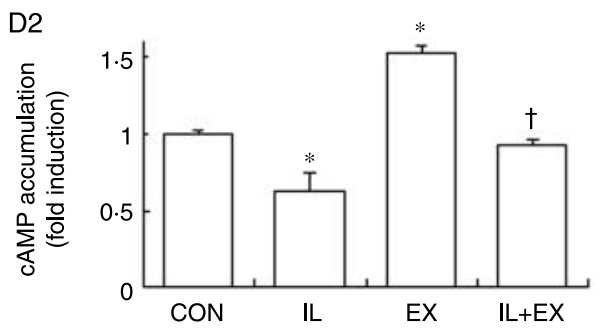

$\mathrm{E}$
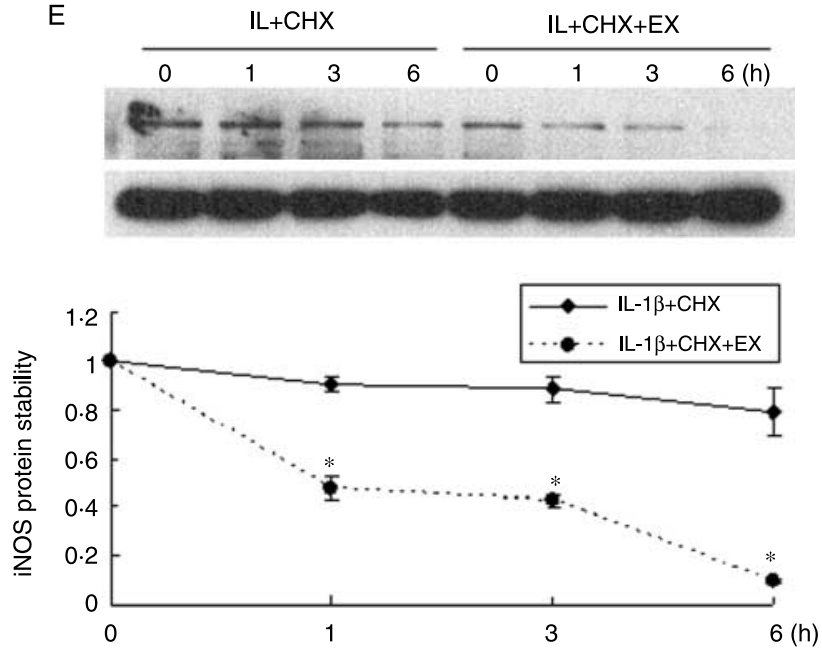

Figure 5 The role of CAMP in exendin-4 inhibition of IL-1 $\beta$-induced iNOS protein in RINm5F cells. (A) The cells were pretreated with H-89 $(5 \mu \mathrm{M})$ for $30 \mathrm{~min}$, next incubated with exendin-4 (EX, $10 \mathrm{nM}$ ) or forskolin (FK, $10 \mu \mathrm{M}$ ) for $1 \mathrm{~h}$, and then cultured with IL-1 13 (IL, $100 \mathrm{pg} / \mathrm{ml}$ ) for an additional $16 \mathrm{~h}$. Western blot analysis for iNOS was performed. Equal loading of protein was verified by probing the same blot for $\beta$-tubulin. Data are expressed as mean ( \pm s.D.) of relative band density $(n=3) .{ }^{*} P<0 \cdot 05$ versus IL; ${ }^{+} P<0 \cdot 05$ versus EX $+\mathrm{IL}$; ${ }^{\ddagger} P<0 \cdot 05$ versus FK+IL. CON, control without any treatment. (B) The effect of forskolin (FK) on IL-induced iNOS promoter activity. The cells were transiently cotransfected with piNOS-LUC $(1 \mu \mathrm{g})$ and pSV- $\beta$-gal $(0 \cdot 1 \mu \mathrm{g}$, as an internal control). Following the serum starvation, the cells were pretreated with FK $(10 \mu \mathrm{M})$ for $30 \mathrm{~min}$, then cultured for an additional $10 \mathrm{~h}$ with IL $(100 \mathrm{pg} / \mathrm{ml})$. Data are expressed as mean \pm s.D. $(n=4)$ and each value is expressed relative to the control value. ${ }^{*} P<0 \cdot 05$ versus CON. (C) The cells were pretreated with PD98059 (PD, $10 \mu \mathrm{M}$ ) or SB203580 (SB, $10 \mu \mathrm{M})$ for $30 \mathrm{~min}$, next incubated with exendin-4 (EX, $10 \mathrm{nM}$ ) for $1 \mathrm{~h}$, and then cultured with IL-1 $\beta$ (IL, $100 \mathrm{pg} / \mathrm{ml})$ for an additional $16 \mathrm{~h}$. Western blot analysis for iNOS was performed. Equal loading of protein was verified by probing the same blot for $\beta$-tubulin. Data are expressed as mean ( \pm s.D.) of relative band density $(n=3) . * P<0 \cdot 05$ versus IL. (D) Measurement of cAMP content. The cells were incubated with EX-4 (10 nM) for $30 \mathrm{~min}$, and then incubated with IL-1 $3(100 \mathrm{pg} / \mathrm{ml})$ for $30 \mathrm{~min}$. The phosphodiesterase inhibitor 3-iosbutyl-1methylxanthine (IBMX, $250 \mu \mathrm{M})$ were added to prevent cAMP breakdown. The cellular cAMP content was measured using cAMP assay kit according to the manufacturer's instructions. Data are expressed as mean \pm s.D. $(n=4)$ and each value is expressed relative to the control value. D1: ${ }^{*} P<0.05$ versus without EX treatment. D2: ${ }^{*} P<0.05$ versus $\mathrm{CON}$; ${ }^{\dagger} P<0.05$ versus IL or EX. (E) iNOS protein stability assay. The cells were incubated with IL-1 $\beta$ (IL, $100 \mathrm{pg} / \mathrm{ml})$ for $16 \mathrm{~h}$, and then exposed to cycloheximide $(\mathrm{CHX} ; 2 \mu \mathrm{g} / \mathrm{ml})$ for $1 \mathrm{~h}$ to stop protein synthesis, and next treated with EX-4 (10 nM) for indicated time points. Western blot analysis for iNOS was performed. Equal loading of protein was verified by probing the same blot for $\beta$-tubulin. Data are expressed as mean $( \pm$ s.D. ) of relative band density $(n=3) . * P<0 \cdot 05$ versus IL only. 


\section{Discussion}

The excessive production of NO via IL-1 $\beta$-stimulated iNOS induction has been implicated in $\beta$-cell damage of type 1 diabetes mellitus (Corbett \& McDaniel 1992, Thomas et al. 2002). NO is highly reactive, and readily converts to toxic peroxynitrite (Bredt \& Snyder 1994). The clinical relevance of $\mathrm{NO}$ in the incidence of type 1 diabetes has been demonstrated in the epidemiologic studies. High intakes of nitrite and $\mathrm{N}$-nitroso compounds were closely related with high incidence of type 1 diabetes (Kostraba et al. 1992, Virtanen et al. 1994).

It is well known that pancreatic $\beta$-cells show remarkably low antioxidant enzyme activities compared with liver or kidney (Lenzen et al. 1996, Tiedge et al. 1997). The RINm5F cell is comparable with the primary $\beta$-cells in the aspects of IL-1 $\beta$-mediated NO production, iNOS expression, and cytotoxicity (Meßmer \& Brüne 1994, Kwon et al. 1995, Larsen et al. 1998). We previously observed that the responses of RINm5F cells to IL-1 $\beta$ were similar to those of the primary isolated islets in nitrite formation and iNOS protein expression (Kim et al. 2003, 2004). These results strongly suggest that RINm5F cells may be an appropriate substitute for the primary $\beta$-cells. Therefore, we sought to define the actions of EX-4, a potent GLP-1 analog, on IL- $1 \beta$-mediated iNOS expression mechanism employing RINm5F $\beta$-cells.

We observed that EX-4 significantly inhibited IL-1 $\beta$-mediated nitrite production and iNOS protein expression consistent with previous studies, in which GLP-1 pretreatment inhibited cytokines- or high glucose-mediated iNOS protein expression in INS-1E cells or diabetic rat islets respectively (Li et al. 2005, Salehi et al. 2008). These results suggest that EX-4 may inhibit the action of IL- $1 \beta$ on iNOS expression at the level of protein or above.

Next, we observed the action of EX-4 on iNOS mRNA expression to examine whether the EX-4 inhibition of iNOS protein level could be attributable to the inhibition of iNOS mRNA content. Unexpectedly, EX-4 did not inhibit iNOS mRNA level induced by IL-1 $\beta$. A similar finding was also reported in another study employing $\mathrm{J} 774$ macrophages (Irace et al. 2007). Oxalomalate, an inhibitor of mitochondrial aconitase, suppressed lipopolysaccharide-induced nitrite production and iNOS protein expression in J774 cells without affecting iNOS mRNA content. To confirm our result of iNOS mRNA, we analyzed the effect of EX-4 on the iNOS promoter activity since the iNOS gene induction is traditionally regulated by the transactivation of iNOS promoter through primary transcription factors including NF- $\kappa B$ (Kleinert et al. 2004). Parallel to the result of iNOS mRNA, EX-4 did not suppress the iNOS promoter activity induced by IL-1 $\beta$. Like EX-4, forskolin, a cAMP-increasing agent, did not inhibit IL-1 $\beta$-stimulated iNOS promoter activity (Fig. 5B) and iNOS mRNA expression (data not shown). These findings suggest that the increase in cAMP level did not inhibit IL-1 $\beta$-induced iNOS at the transcriptional level. We further evaluated the effect of EX-4 on the action of NF- $\kappa \mathrm{B}$ since the importance of $\mathrm{NF}-\kappa \mathrm{B}$ binding sites has been well known for the induction of iNOS promoter activity (Spink et al. 1995, Eberhardt et al. 1998). Consistent with the result of iNOS promoter study, EX-4 did not suppress IL- $1 \beta$-stimulated binding activity of NF- $\kappa B$ to the iNOS promoter and did not inhibit IL-1 $\beta$-mediated nuclear translocation of $\mathrm{p} 65$, an NF- $\mathrm{BB}$ subunit. These findings indicate that EX-4 seems to inhibit iNOS expression at the protein level, but not at the transcriptional level.

Besides the transcriptional regulation, the posttranscriptional mechanism is also involved in the induction of iNOS gene expression (Kleinert et al. 2004). Therefore, to further explore whether EX-4 inhibition of IL-1 $\beta$-induced iNOS protein expression was attributable to the instability of iNOS mRNA following the transcription of iNOS gene, we analyzed the role of EX-4 in the posttranscriptional regulation of iNOS mRNA. Our actinomycin D chase study shows that EX-4 did not affect the degradation rate of iNOS mRNA induced by IL-1 $\beta$. The $3^{\prime}$-UTR of rat iNOS mRNA has six AU-rich elements (ARE, AUUUA), which interact with ARE-binding proteins including HuR and polypyrimidine tract-binding protein, contributing to iNOS mRNA stability (Kleinert et al. 2004, Pautz et al. 2006). Therefore, we analyzed the effect of EX-4 on iNOS mRNA stability using $3^{\prime}$-UTR-containing luciferase construct (Fig. 4B). In this study, the presence of $3^{\prime}$-UTR significantly reduced the luciferase activity in basal conditions while the treatment of IL-1 $\beta$ profoundly increased the luciferase activity. These findings are supported by other studies. In the human iNOS, $3^{\prime}$-UTR affected the gene regulation by decreasing its basal expression, however, $3^{\prime}$-UTR significantly induced the gene expression upon the treatment of cytokine mixture (Nunokawa et al. 1997). Consistent with the result of actinomycin D chase experiment, EX-4 did not affect the luciferase activity induced by IL-1 $\beta$. Therefore, EX-4 may not affect iNOS gene expression at the posttranscriptional level.

The involvement of proteasome in iNOS protein degradation has been suggested in some cells. In mouse peritoneal macrophage, transforming growth factor- $\beta$ reduced IFN- $\gamma$-stimulated iNOS protein level via increased degradation of the protein (Vodovotz et al. 1993). The iNOS protein is primarily regulated by proteasome pathway in Raw264.7 and HEK294 cells (Walker et al. 1997, Musial \& Eissa 2001, Kolodziejski et al. 2002). However, in islet $\beta$-cells, knowledge concerning the role of ubiquitinproteasome pathway in iNOS protein degradation is very limited. Pituitary adenylate cyclase-activating polypeptide 27, a cAMP-producing peptide suppressed iNOS expression in lipid-infused rat islets, which was not reversed by the treatment of a proteasome inhibitor MG 132 (Qader et al. 2007). Additionally, MG132 did not reverse the GLP-1-induced suppression of iNOS expression in diabetic GK rat islets, but instead MG132 induced loss of iNOS protein (Salehi et al. 2008). These findings suggest that the 
suppressive effect of cAMP-increasing agents on iNOS protein expression may be exerted via non-proteasomal mechanisms. Moreover, GLP-1 inhibited IFN- $\gamma$-induced $\mathrm{NO}$ production via suppression of $\mathrm{TNF}-\alpha$ production in MIN6N8a cells (Hahm et al. 2008). Therefore, to clarify the mechanism of EX-4 inhibition of IL-1 $\beta$-induced iNOS protein expression, further studies including both proteasomal and non-proteasomal pathways will be required.

Growing evidence suggests that cAMP inhibits most inflammatory reactions such as the production of inflammatory cytokines and oxidative burst (Ottonello et al. 1995, Willis \& Nisen 1995). However, the role of cAMP in iNOS expression is different depending on the cell types (Galea \& Feinstein 1999). In rat, peritoneal macrophages and macrophage cell lines, cAMP upregulated iNOS expression (Sowa \& Przewlocki 1994, Jeon et al. 1996) or inhibited it (Marotta et al. 1992, Pang \& Hoult 1997). Moreover, cAMP potentiated iNOS expression in aortic smooth muscle (Koide et al. 1993), brown adipose tissue (Nisoli et al. 1997), and brain endothelium (Durieu-Trautmann et al. 1993) while cAMP decreased iNOS expression in pancreatic cells (Andersen et al. 1996) and rat hepatocytes (Smith et al. 1997).

Therefore, we examined the involvement of signaling molecules in the EX-4 inhibition of IL-1 $\beta$-induced iNOS protein since cAMP/PKA system induced by GLP-1 or EX-4 is a critical signaling pathway for $\beta$-cell survival and growth (Jhala et al. 2003). The present study showed that forskolin, a cAMP increasing agent significantly inhibited IL$1 \beta$-induced iNOS protein expression and that the inhibitory effects of EX-4 and forskolin were reversed by H-89, a PKA inhibitor (Fig. 5A). Dibutyryl-cAMP, a membrane permeable cAMP analog also had a similar effect to forskolin (data not shown). These findings are consistent with others' reports. GLP-1 suppressed high glucose-stimulated iNOS expression in normal islet tissue and excessive expression of iNOS in diabetic GK rat islets, and these effects were reversed by PKA inhibition (Jimenez-Feltstrom et al. 2005, Salehi et al. 2008). A few previous studies, though not the study of GLP-1, indicate that $\mathrm{CAMP} / \mathrm{PKA}$ signaling pathway was involved in IL-1 $\beta$-induced iNOS expression. IL-1-induced nitrite production was antagonized by lipophilic cAMP such as CPT-cAMP and 8-Br-cAMP (Meßmer \& Brüne 1994). In the isolated islets, IL-1 $\beta$-induced nitrite production was reduced by 3-isobutyl-1-methyl xanthine, a phosphodiesterase inhibitor (Andersen et al. 1996).

Meanwhile, GLP-1 and EX-4 have been known to induce the phosphorylation of ERK in $\beta$-cells (Buteau et al. 2001, Arnette et al. 2003, Kim et al. 2006), and so we tested ERK pathway in iNOS protein expression. PD98059, an MEK inhibitor did not alter IL-1 $\beta$-induced iNOS protein expression, which is supported by another study that found that the inhibition of MAP kinase pathway by PD98059 had no effect on the anti-apoptotic function of liraglutide, a longacting GLP-1 analog (Bregenholt et al. 2005).

To further evaluate the role of cAMP/PKA pathway in iNOS protein expression, intracellular cAMP content was measured. EX-4 produced cAMP formation dose-dependently $(0 \cdot 1-10 \mathrm{nM})$, however, a higher concentration of EX-4 $(100 \mathrm{nM})$ failed to increase cAMP production (Fig. 5D1). These findings were consistent with the results of another study (Sidhu et al. 2005). Additionally, EX-4 treatment restored the IL-1 $\beta$-induced decrease in cAMP level toward normal control level (Fig. 5D2). Based on this finding, we observed iNOS protein stability using cycloheximide to identify the role of cAMP in iNOS protein degradation (Fig. 5E). EX-4 significantly increased iNOS protein degradation compared with control. Forskolin also showed a similar effect to EX-4 (data not shown). Accordingly, the present findings indicate that the increase in cAMP level seems to be involved in iNOS protein degradation by EX-4.

In conclusion, we suppose that the EX-4-activated cAMP/PKA pathway may be involved in the suppression of IL-1 $\beta$-induced iNOS expression at posttranslational level (iNOS protein stability) without affecting transcriptional and posttranscriptional levels.

\section{Declaration of interest}

The authors declare that there is no conflict of interest that could be perceived as prejudicing the impartiality of the research reported.

\section{Funding}

This study was supported by the Korean Diabetes Association.

\section{Acknowledgements}

We are very thankful to the financial support of Korean Diabetes Association (2008). And we appreciate Dr Yong-Moon Park (Department of Preventive Medicine, College of Medicine, The Catholic University of Korea) for the statistical analysis.

\section{References}

Andersen HU, Mauricio D, Karlsen AE, Mandrup-Poulsen T, Nielsen JH \& Nerup J 1996 Interleukin-1 $\beta$-induced nitric oxide production from isolated rat islets is modulated by D-glucose and 3-isobutyl-1-methyl xanthine. European Journal of Endocrinology 134 251-259.

Andre IA, Gonzalez B, Wang J, Benoist KC \& Mathis D 1996 Checkpoints in the progression of autoimmune disease: lessons from diabetes models. PNAS 93 2260-2263.

Arnette D, Gibson TB, Lawrence MC, January B, Khoo S, McGlynn K, Vanderbilt CA \& Cobb MH 2003 Regulation of ERK1 and ERK2 by glucose and peptide hormone in pancreatic $\beta$ cells. Journal of Biological Chemistry 278 32517-32525.

Baggio LL \& Drucker DJ 2007 Biology of incretins: GLP-1 and GIP. Gastroenterology 132 2131-2157.

Belin VD, Mabley JG, James RFL, Swift SM, Clayton HA, Titheradge MA \& Green IC 1999 Glucagon decreases cytokine induction of nitric oxide synthase and action on insulin secretion in RINm5F cells and rat and human islets of Langerhans. Cytokine 11 585-592.

Bredt DS \& Snyder SH 1994 Nitric oxide: a physiologic messenger molecule. Annual Review of Biochemistry 63 175-195. 
Bregenholt S, Møldrup A, Blume N, Karlsen AE, Friedrichsen BN, Tornhave D, Knudsen LB \& Petersen JS 2005 The long-acting glucagons-like peptide-1 analogue, liraglutide, inhibits $\beta$-cell apoptosis in vitro. Biochemical and Biophysical Research Communications 330 577-584.

Bulotta A, Farilla L, Hui H \& Perfetti R 2004 The role of GLP-1 in the regulation of islet cell mass. Cell Biochemistry and Biophysics 40 65-78.

Buteau J, Foisy S, Rhodes CJ, Carpenter L, Biden TJ \& Prentki M 2001 Protein kinase $\mathrm{C} \zeta$ activation mediates glucagon-like peptide-1-induced pancreatic $\beta$-cell proliferation. Diabetes 50 2237-2243.

Corbett JA \& McDaniel ML 1992 Does nitric oxide mediate autoimmune destruction of beta-cells? Possible therapeutic interventions in IDDM Diabetes 41 897-903.

Drucker DJ, Philippe J, Mojsov S, Chick WL \& Habener JF 1987 Glucagonlike peptide-1 stimulates insulin gene expression and increases cyclic AMP levels in a rat islet cell line. PNAS 84 3434-3438.

Durieu-Trautmann O, Bourdoulous S, Roux F, Bourre JM, Strosberg AD \& Couraud PO 1993 Immortalized rat brain microvessel endothelial cells: II. Pharmacological characterization. Advances in Experimental Medicine and Biology 331 205-210.

Eberhardt W, Pluss C, Hummel R \& Pfeilschifter J 1998 Molecular mechanisms of inducible nitric oxide synthase gene expression by IL-1 $\beta$ and cAMP in rat mesangial cells. Journal of Immunology 160 4961-4969.

Egan JM, Bulotta A, Hui H \& Perfetti R 2003 GLP-1 receptor agonists are growth and differentiation factors for pancreatic islet beta cells. Diabetes/Metabolism Research and Reviews 19 115-123.

Galea E \& Feinstein DL 1999 Regulation of the expression of the inflammatory nitric oxide synthase (NOS2) by cyclic AMP. FASEB Journal $132125-2137$

Hahm E, Lee YS \& Jun HS 2008 Suppressive effects of glucagons-like peptide- 1 on interferon- $\gamma$-induced nitric oxide production in insulin-producing cells is mediated by inhibition of tumor necrosis factor- $\alpha$. production. Journal of Endocrinological Investigation 31 334-340.

Ho E \& Bray TM 1999 Antioxidants, NF- $\kappa B$ activation, and diabetogenesis. Proceedings of the Society for Experimental Biology and Medicine 222 205-213.

Irace C, Esposito G, Maffettone C, Rossi A, Festa M, Iuvone T, Sautebin L, Carnuccio R \& Colonna A 2007 Oxalomalate affects the inducible nitric oxide synthase expression and activity. Life Sciences 80 1282-1291.

Jeon YJ, Yang KH, Pulaski JT \& Kaminski NE 1996 Attenuation of inducible nitric oxide synthase gene expression by $\Delta^{9}$-tetrahydrocannabinol is mediated through the inhibition of nuclear factor- $\mathrm{Kb} / \mathrm{Rel}$ activation. Molecular Pharmacology 50 334-341.

Jhala US, Canettieri G, Screaton RA, Kulkarni RN, Krajewski S, Reed J, Walker J, Lin X, White M \& Montminy M 2003 cAMP promotes pancreatic beta-cell survival via CREB-mediated induction of IRS2. Genes and Development 17 1575-1580.

Jimenez-Feltstrom J, Lundquist I \& Salehi A 2005 Glucose stimulates the expression and activities of nitric oxide synthase in incubated rat islets: an effect counteracted by GLP-1 through the cyclic AMP/PKA pathway. Cell and Tissue Research 319 221-230.

Kang JH, Kim MJ, Ko SH, Jeong IK, Koh KH, Rhie DJ, Yoon SH, Hahn SJ, Kim MS \& Jo YH 2006 Upregulation of rat CCND1 gene by exendin-4 in pancreatic beta-cell line INS-1: interaction of early growth response-1 (Egr-1) with cis-regulatory element. Diabetologia 49 969-979.

Kang JH, Kim MJ, Jang HI, Koh KH, Yeom KS, Rhie DJ, Yoon SH, Hahn SJ, Kim MS \& Jo YH 2007 Proximal cyclic AMP response element is essential for exendin-4 induction of rat EGR-1 gene. American Journal of Physiology. Endocrinology and Metabolism 292 E215-E222.

Kim MJ, Ryu GR, Chung JS, Sim SS, Min DS, Rhie DJ, Yoon SH, Hahn SJ, Kim MS \& Jo YH 2003 Protective effects of epicatechin against the toxic effects of streptozotocin on rat pancreatic islets: in vivo and in vitro. Pancreas 26 292-299.

Kim MJ, Ryu GR, Kang JH, Sim SS, Min DS, Rhie DJ, Yoon SH, Hahn SJ, Jeong IK, Hong KJ et al. 2004 Inhibitory effects of epicatechin on interleukin-1-induced inducible nitric oxide synthase expression in RINm5F cells and rat pancreatic islets by down-regulation of NF- $\kappa \mathrm{B}$ activation. Biochemical Pharmacology 68 1775-1785.
Kim MJ, Kang JH, Park YG, Ryu GR, Ko SH, Jeong IK, Koh KH, Rhie DJ, Yoon SH, Hahn SJ et al. 2006 Exendin-4 induction of cyclin D1 expression in INS-1 beta-cells involvement of cAMP response-like element. Journal of Endocrinology 188 623-633.

Kim MJ, Kang JH, Chang SY, Jang HJ, Ryu GR, Ko SH, Jeong IK, Kim MS \& Jo YH 2008 Exendin-4 induction of Egr-1 expression in INS-1 betacells: interaction of SRF, not YY1, with SRE site of rat Egr-1 promoter. Journal of Cellular Biochemistry 104 2261-2271.

Kleinert H, Pautz A, Linker K \& Schwarz PM 2004 Regulation of the expression of inducible nitric oxide synthase. European Journal of Pharmacology 500 255-266.

Koide M, Kawahara Y, Nakayama I, Tsuda T \& Yokoyama M 1993 Cyclic AMP-elevating agents induce an smooth muscle cells. Synergism with the induction elicited by inflammatory cytokines. Journal of Biological Chemistry 268 24959-24966.

Kolodziejski PJ, Musial A, Koo JS \& Eissa NT 2002 Ubiquitination of inducible nitric oxide synthase is required for its degradation. PNAS 99 $12315-12320$.

Kostraba JN, Gay EC, Rewers M \& Hamman RF 1992 Nitrite levels in community drinking waters and risk of IDDM. Diabetes Care $\mathbf{1 5}$ $1505-1508$.

Kutlu B, Cardozo AK, Darville MI, Kruhøffer M, Magnusson N, Ørntoft T \& Eizirik DL 2003 Discovery of gene networks regulating cytokine-induced dysfunction and apoptosis in insulin-producing INS-1 cells. Diabetes $\mathbf{5 2}$ 2701-2719.

Kwon G, Corbett JA, Rodi CP, Sullivan P \& McDaniel ML 1995 Interleukin$1 \beta$-induced nitric oxide synthase expression by rat pancreatic $\beta$-cells: evidence for the involvement of nuclear factor $\mathrm{\kappa B}$ in the signaling mechanism. Endocrinology 136 4790-4795.

Larsen CM, Wadt KAW, Juhl LF, Anderswn HU, Karlsen AE, Su MS-S, Seedorf K, Shapiro L, Dinarello CA \& Mandrup-Poulsen T 1998 Interleukin- $1 \beta$-induced rat pancreatic islet nitric oxide synthesis requires both the p38 and extracellular signal-regulated kinase 1/2 mitogen-activated protein kinase. Journal of Biological Chemistry 273 15294-15300.

Leech CA, Castonguay MA \& Habener JF 1999 Expression of adenylyl cyclase subtypes in pancreatic $\beta$-cells. Biochemical and Biophysical Research Communications 254 703-706.

Lenzen S, Drinkgern J \& Tiedge M 1996 Low antioxidant enzyme gene expression in pancreatic islets compared with various other mouse tissues. Free Radical Biology and Medicine 20 463-466.

Li L, El-Kholy W, Rhodes CJ \& Brubaker PL 2005 Glucagon-like leptide-1 protects beta cells from cytokine-induced apoptosis and necrosis: role of protein kinase B. Diabetologia 48 1339-1349.

List JF \& Habener JF 2004 Glucagon-like peptide-1 agonists and the development and growth of pancreatic $\beta$-cells. American Journal of Physiology. Endocrinology and Metabolism 286 E875-E881.

Mandrup-Poulsen T 1996 The role of interleukin-1 in the pathogenesis of IDDM. Diabetologia 39 1005-1029.

Mandrup-Poulsen T 2001 Beta-cell apoptosis: stimuli and signaling. Diabetes 50 58-63.

Marotta P, Sautebin L \& Dirosa M 1992 Modulation of the induction of nitric oxide synthase by eicosanoids in the murine macrophage cell line J774 British Journal of Pharmacology 107 640-641.

Meßmer UK \& Brüne B 1994 Modulation of inducible nitric oxide synthase in RINm5F cells. Cellular Signalling 6 17-24.

Musial A \& Eissa NT 2001 Inducible nitric-oxide synthase is regulated by the proteasome degradation pathway. Journal of Biological Chemistry 276 24268-24273.

Nisoli E, Tonello C, Briscini L \& Carruba MO 1997 Inducible nitric oxide synthase in rat brown adipocytes: implications for blood flow to brown adipose tissue. Endocrinology 138 676-682.

Nunokawa Y, Oikawa S \& Tanaka S 1997 Expression of human inducible nitric oxide synthase is regulated by both promoter and $3^{\prime}$-region. Biochemical and Biophysical Research Communications 233 523-526.

Ørskov C 1992 Glucagon-like peptide-1, a new hormone of the entero-insular axis. Diabetologia 35 701-711. 
Ottonello L, Morone MP, Dapino P \& Dallegri F 1995 Cyclic AMP-elevating agents down-regulate the oxidative burst induced by granulocytemacrophage colony-stimulating factor (GM-CSF) in adherent neutrophils. Clinical and Experimental Immunology 101 502-506.

Pang L \& Hoult JR 1997 Repression of inducible nitric oxide synthase and cyclooxygenase- 2 by prostaglandin $\mathrm{E}_{2}$ and other cyclic AMP stimulants in J774 macrophages. Biochemical Pharmacology 53 493-500.

Pautz A, Linker K, Hubrich T, Korhonen R, Altenhofer S \& Kleinert H 2006 The polypyrimidine tract-binding protein (PTB) is involved in the post-transcriptional regulation of human inducible nitric oxide synthase expression. Journal of Biological Chemistry 281 32294-32302.

Qader SS, Jimenez-Feltström J, Ekelund M, Lundquist I \& Salehi A 2007 Expression of islet inducible nitric oxide synthase and inhibition of glucose-stimulated insulin release after long-term lipid infusion in the rat is counteracted by PACAP27. American Journal of Physiology. Endocrinology and Metabolism 29 E1447-E1455.

Rabinovitch A 1998 An update on cytokines in the pathogenesis of insulin-dependent diabetes mellitus. Diabetes/Metabolism Reviews 1 215-240.

Salehi A, Abaraviciene SM, Jimmenez-Feltstrom J, Östenson CG, Efendic S \& Lundquist I 2008 Excessive islet NO generation in type 2 diabetic GK rats coincides with abnormal hormone secretion and is counteracted by GLP-1. PLOS ONE 3 e2165.

Salehi A, Carlberg M, Henningson R \& Lundquist I 1996 Islet constitutive nitric oxide synthase: biochemical determination and regulatory function. American Journal of Physiology 270 C1634-C1641.

Sidhu KK, Fowkes RC, Skelly RH \& Burrin JM 2005 Exogenous expression of glucagons-like peptide 1 receptor in AtT-20 corticotrophs confers cAMP-mediated gene transcription and insulin secretion. Journal of Endocrinology 187 419-427.

Smith FS, Ceppi ED \& Titheradge MA 1997 Inhibition of cytokine-induced inducible nitric oxide synthase expression by glucagons and cAMP in cultured hepatocytes. Biochemical Journal 326 187-192.

Southern C, Schulster D \& Green IC 1990 Inhibition of insulin secretion by interleukin- $1 \beta$ and tumor necrosis factor- $\alpha$ via an L-arginine-dependent nitric oxide generation. FEBS Letters 276 42-44.

Sowa G \& Przewlocki R 1994 cAMP analogues and cholera toxin stimulate the accumulation of nitrite in rat peritoneal macrophage cultures. European Journal of Pharmacology 266 125-129.
Spink JM, Cohen J \& Evans T 1995 Delineation of the vsmc iNOS enhancer and its interaction with the transcription factor, relA. Endothelium 3 S50.

Stoffers DA 2004 The development of beta-cell mass: recent progress and potential role of GLP-1. Hormone and Metabolic Research 36 811-821.

Susini S, Roche E, Prentki M \& Schlegel W 1998 Glucose and glucoincretin peptides synergize to induce $c$-fos, $c-j u n, j u n B, z i f-268$, and nur-77 gene expression in pancreatic $\beta$ (INS-1) cells. FASEB Journal 12 1173-1182.

Tabatabaie T, Vasquez-Weldon A, Moore DR \& Kotake Y 2003 Free radicals and the pathogenesis of type 1 diabetes: $\beta$-cell cytokine-mediated free radical generation via cyclooxygenase-2. Diabetes 52 1994-1999.

Thomas HE, Darwiche R, Corbett JA \& Kay TWH 2002 Interleukin-1 plus $\gamma$-interferon-induced pancreatic $\beta$-cell dysfunction is mediated by $\beta$-cell nitric oxide production. Diabetes 51 311-326.

Tiedge M, Lotz S, Drinkgern J \& Lenzen S 1997 Relation between antioxidant enzyme gene expression and antioxidative defense status of insulin-producing cells. Diabetes 46 1733-1742.

Virtanen SM, Jaakkola L, Räsänen L, Ylönen K, Aro A, Lounamaa R, Äkerblom HK, Tuomilehto J \& the Childhood Diabetes in Finland Study Group 1994 Nitrate and nitrite intake and the risk for type 1 diabetes in Finnish children. Diabetic Medicine 11 656-662.

Vodovotz Y, Bogdan C, Paik J, Xie Q \& Nathan C 1993 Mechanisms of suppression of macrophage nitric oxide release by transforming growth factor $\beta$. Journal of Experimental Medicine 178 605-613.

Walker G, Pfeilschifter J \& Kunz D 1997 Mechanisms of suppression of inducible nitric-oxide synthase (iNOS) expression in interferon (IFN)- $\gamma$-stimulated RAW 264.7 cells by dexamethasone. Evidence for glucocorticoid-induced degradation of iNOS protein by calpain as a key step in post-transcriptional regulation. Journal of Biological Chemistry $\mathbf{2 7 2}$ 16679-16687.

Willis SA \& Nisen PD 1995 Inhibition of lipopolysaccharide-induced IL-1 $\beta$ transcription by cyclic adenosine monophosphate in human astrocytic cells. Journal of Immunology 154 1399-1406.
Received in final form 20 April 2009
Accepted 27 April 2009
Made available online as an Accepted Preprint 27 April 2009 